A DICTIONARY OF LITERARY DEVICES 
$\mathrm{ABC}$ or gradus ad Parnassum [stairway to Parnassus, the seat of the Muses], for those who might like to learn. The book is not addressed to those who have arrived at full knowledge of the subject without knowing the facts.

Ezra Pound, $A B C$ of Reading 


\section{Bernard Dupriez}

\section{A DICTIONARY \\ OF LITERARY \\ DEVICES \\ GRADUS, A-Z}

Translated and adapted by

Albert W. Halsall 
www.utppublishing.com

(C) University of Toronto Press 1991

Toronto and Buffalo

Printed in Canada

ISBN 0-8020-2756-3 (cloth)

ISBN 0-8020-6803-0 (paper)

Originally published in French as

Gradus: les procédés littéraires (Dictionnaire)

(C) Union générale d'éditions 1984

$\infty$

Printed on acid-free paper

\section{Canadian Cataloguing in Publication Data}

Dupriez, Bernard, 1933-

A dictionary of literary devices

Translation of: Gradus: les procédés littéraires.

Includes bibliographical references and index.

ISBN 0-8020-2756-3 (bound) ISBN 0-8020-6803-0 (pbk.)

1. Rhetoric - Dictionaries. 2. Poetics -

Dictionaries. I. Halsall, A.W. (Albert W.).

II. Title.

PN172.D813 $1991 \quad 808^{\prime} .003 \quad$ C91-093568-8 
For Mary, Alison, and Colin 
This page intentionally left blank 